\title{
READERS
Insight
}

Journal of Management Info (JMI)

ISSN:2313-3376

www.readersinsight.net/jmi

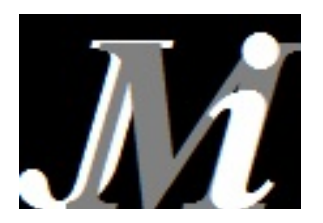

\section{Business continuity management factors and organizational performance: a study on the moderating role of it capability}

\author{
Zahari Abu Bakar ${ }^{1 *}$, Noorulsadiqin Azbiya Yaacob², Zulkifli Mohamed Udin³ \\ ${ }^{1,2,3}$ College of Business, Universiti Utara Malaysia, 06010 Sintok, Kedah Darul Aman, Malaysia \\ *Corresponding author: zzzahari@gmail.com
}

Abstract

The objective of this paper is to examine the moderating effect of IT capability on the relationship between Business Continuity Management (BCM) factors and the organizational performance. The constructs of this paper are defined based on a comprehensive review of recent literature on BCM, organizational performance and IT capability. For this study, the data was collected through various methods including self-administered approach and distribution of questionnaires via electronic and conventional mail. The target population of the study is organizations which are certified with ISO 27001 and ISO 2230 . These organizations are selected as they are deemed to possess considerably higher sense of commitment towards embracing BCM best practices to enhance their business resiliency. The findings of this study indicated that IT capability partially moderated the relationship between BCM factors and organizational performance. The outcome of this study provides important insight to researchers and BCM professionals in understanding on the effects of BCM factors and IT capability on the organizational performance.

\section{ARTICLE INFORMATION}

$\begin{array}{ll}\text { Received: } & 25 \text { April } 2015 \\ \text { Revised: } & 25 \text { May } 2015\end{array}$

Accepted: 25 June 2015

DOI:

http://dx.doi.org//10.31580/jmi.v7i1.38

Keywords: Business Continuity Management, organizational performance, IT capability, ISO 27001, ISO 22301

\section{Introduction}

Naturally, business disruptions of any sort could have extremely damaging repercussions to an organization, not only in terms of tangible financial losses, but also intangible effects on the corporate reputation and customers' confidence. It is therefore, a critical business imperative that a working plan should be established to ensure that in the event of an unforeseen disruption, critical business functions will be resumed as effectively and quickly as possible. Similarly, organizations desiring to stay competitive and successful must be well protected, through heightened resiliency so that it could remain profitably in the event of any fatal business disruption. According to Wong (2009), organizations that incorporate Business Continuity Management (BCM) in their strategic management could gain a distinctive competency over their competitors in terms of operational resiliency which includes the speedy recovery of critical business functions at predefined period of time while minimizing the adverse impacts to their value and reputation. For instance, the impacts of the September 11 tragedy on many businesses were disastrous where many organizations failed to recover their operations in timely manner after the incident. Nonetheless, those organizations which had comprehensive BCM program in place were able to demonstrate high resiliency and had their services recovered within a few hours or days after the incident. A good example was Dow Jones which had about 800 employees on floors 9 to 12 and 14 to 16 of the World Trade Centre, all of its employees survived and no loss of data or services was reported during the disaster period. This was mainly because Dow Jones had a comprehensive and effective BCM program in practice (Childs \& Dietrich, 2002). Likewise, other organizations like American Express and Merrill Lynch which also had a large presence in the World Trade Centre, were back in business in hours after the tragedy, due to the fact that they had well developed BCM plans. Furthermore, NASDAQ, an American stock exchange which also had a BCM program in place, managed to resume its services in a few days following the incident (Hecht, 2002).

Hence, the demand to protect the continuity of critical business services in the event of an unforeseen disruption has become more critical than ever. Any critical operational failure may cause a degradation of service quality and even a monetary loss if the duration or degree of business interruption is extensive (Yiu \& Tse, 1995). According to the Gartner Group report in 2004, it was revealed that the average cost of service downtime worldwide was at USD 42,000 per hour per incident (Vancoppenolle, 2007). A recent survey conducted by KPMG (2014) reported that the cost of downtime for the past twelve months is estimated to be over USD 100,000 for 36 percent of the organization, with almost 12 percent reporting losses at over USD 1 million while over 28 percent indicated that they 'do not know' the total cost of the downtime. However, the downtime costs will vary significantly depending on the industries, size of business and the nature of disaster. Beside the direct monetary lost, the downtime may also affect corporate reputation, branding, customer loyalty, regulatory compliance and employee productivity. Based on these facts, it is undeniable that an effective BCM plays a very crucial role in ensuring an organization's survivability and to remain competitive.

Indeed, information technology (IT) has become the most effective tools that could generate extremely invisible capability in the competitive era of K-economy. Li, Chen and Huang (2006) posited that the capability has been recognized in creating significant influence on organization's performance. Several studies have 
revealed that an organization's capabilities are more difficult to be replicated or imitated than the organization's resources. The review of past studies that focus on a direct relationship between IT and organizational performance fail to consider capabilities, that are improved by IT and which are the true facilitators of performance enhancement (Tippins \& Sohi, 2003). There are also other studies that have relied on the erroneous assumption that adoption of IT would improve performance (Dewett \& Jones, 2001). Though IT can improve efficiency, it may not necessarily give competitive advantage since similar technology could be replicated by the competitors. As such, Tippins and Sohi (2003) postulates that benefit can only be realized when the organization develops IT competency and then utilizes it as a set of co-specialized resources to leverage other complementary resources. For this study, the dynamic capability in form of IT capability was introduced to address the theoretical limitation of having sustainable performance in turbulent business environment (Paulous, 2004).

\section{Problem statement}

There are challenges faced by the BCM professionals in developing and maintaining the $\mathrm{BCM}$ infrastructure and activities. With all the expenditure associated with the preparation of essential BCM infrastructures and resources such as planning and consulting, setting up the hot-site data center and operation center and acquisition of additional hardware and software, it is crucial to present a solid business case in order to gain top management's buy in (Petroni, 1999). Peterson (2009) argued that one of the reasons many organizations fail to implement effective BCM is due to lack of financial support as great prudence in expenditures is exercised by many senior management and the board of directors. This situation may be due to there is no direct financial benefit or return of investment is seen from the BCM implementation. In order to successfully secure the funding, IT professionals should work together with the business owners to estimate the potential loss due to service downtime, identify the likelihood of risks, define the optimum recovery objectives and choose the most cost effective solution and technology (Belaouras, 2009). Another challenge is deploying BCM in organizations which cut across several business units or implementing it on a corporate enterprise wide basis (Belaouras, 2009). These situations emphasize the importance of senior management support and directive to mandate the priority of $\mathrm{BCM}$ initiatives across all organization members.

In order to address the above challenges, understanding the potential benefits of $\mathrm{BCM}$ on the organizational performance is important to give a proper merit to the BCM efforts and draw attention and subsequently, obtaining full support from the senior management. Sawalha (2013) suggests that understanding the effects of BCM on organizational performance is significant since BCM is one of the primary driving factors for enhancing an organization's ability to withstand its resiliency, as well as survival under extreme internal and external pressures. The previous studies which focused on the strategic role of BCM argued that BCM could become a source of competitive advantage for organizations but these studies did not deliberated comprehensively on how BCM can contribute to organizational performance specifically (Herbane, Elliott, \& Swartz, 2004). The available literature presents several studies that deliberate risk management in relation to the organizational performance. These studies have concluded that understanding the likelihood and impact of potential disaster events can enhance organizational performance (Alesi, 2008; Herbane et al., 2004; Herbane, 2010; Selden \& Perks, 2007). On the same ground, Sawalha (2013) belief that, similar to risk management which is considered the roots of BCM, BCM could also play an important role that may contribute to the optimization of organizational performance. In addition, Sawalha (2013) also highlighted that the role of $\mathrm{BCM}$ in enhancing organizational performance has rarely been deliberated or even addressed in the existing studies.

Notably, the major theoretical gaps in the present literature observed in this research lies in the insufficient studies which have investigated and established the relationships between BCM factors and organizational performance. Hence, the goal of this study is to extend the limited literature on the relationship that exists between BCM factors and organizational performance. As for the organizational performance dimensions, this study will consider multiple performance measurements which include financial and non-financial indicators. As IT is seen as one of the main driver of BCM, this study will also investigate the influence of IT capability on the relationship between BCM factors and organizational performance.

\section{Literature review}

\section{Business continuity management}

BCM has its roots from Disaster Recovery Planning (DRP) practices that emerged during the 1950s and 1960s where companies began to store backup media copies of their critical information, paper or electronic at alternate sites (Randeree, Mahal, \& Narwani, 2012). DRP originated from the desire of banks in United States to better protect their corporate data centers from disastrous events. During that time, the goal of DRP was to protect the computer systems rather than providing organizational wide or business side protection. Later, in 1990s, there was a major paradigm shift from traditional DRP to Business Continuity Planning (BCP) (Herbane, 2010). The BCP scope was much broader than DRP and it was prepared for incidents that might affect critical business services in an organization. Since then, the scope of BCP was expanded to enhance the value to the organization as a whole and broaden out its focus to include the stakeholders (Elliott, Swartz, \& Herbane, 2010a). This expansion of focus shaped the BCM approach which includes enterprise wide and external factors. The below Figure 1 illustrates the evolution of BCM's period, drivers, practices and nature of progress (Herbane, 2010).

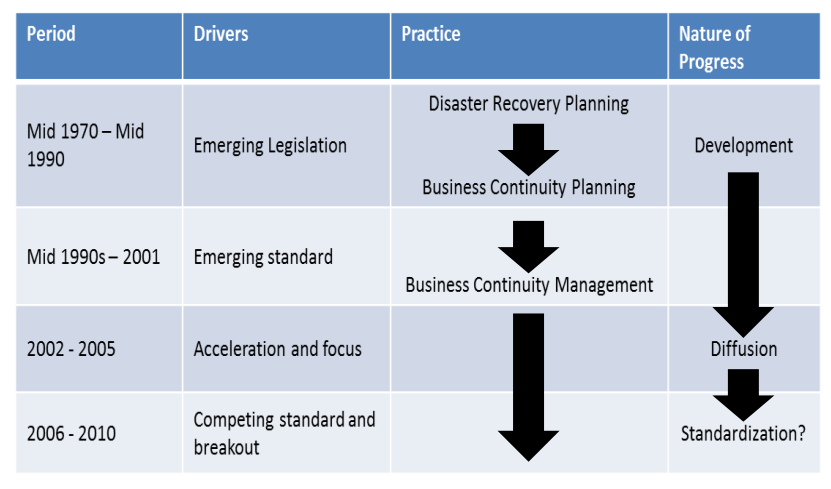

Fig. 1. The evolution of $\mathrm{BCM}$

\section{BCM Factors}

Critical success factor is defined as few performance measures of which, if they are accomplished satisfactorily, they will assure successful competitive performance for the organization. Rockart (1979) asserted that they are the things that must go right and for that reason, special attention must be given to these factors.

Based on current literature, there are various critical success factors of $\mathrm{BCM}$ and for the purpose of this study, the critical success factors are also referred as factors. This study will focus on examining the selected BCM critical success factors adapted from previous studies (Chow \& Ha, 2009; Chow, 2000; Herbane et al., 2004; Hoong, 2011; Järveläinen, 2013; Karim, 2011). The selected BCM factors will be used as the independent variables in this study, which include 1) management support, 2) external requirements, 3) organization preparedness, and 4) embeddedness of continuity practices. These four factors are selected as their definitions and scopes able to represent all of the critical success factors from the past studies. 
Furthermore, these factors are important elements to ensure the successful implementation of BCM in an organization.

\section{Organizational performance and BCM}

The current literature presents a number of studies that deliberate risk management and its relation to organizational performance. According to Sawalha (2013), these studies have indicated that by understanding the impact and likelihood of potential incidents, it could enhance the organizational performance. In this context, risk management is exercised by organization to minimize the adverse impacts of internal and external risks that may affect its activities and performance. Risk management also supports organizations in responding to uncontrollable market conditions to sustain consistent profitability, which eventually leads to optimized organizational performance (Jafari, Chadegani, \& Biglari, 2011; Saleem, 2011). Understanding the effects of $\mathrm{BCM}$ on organizational performance is crucial because BCM is one of the key driving forces to strengthen firm's ability to withstand risks and survive under extreme organizational and environmental pressures. According to Sawalha (2013), the role of BCM in enhancing organizational performance has rarely been investigated or even discussed in the existing literature. He belief that, similar to the objective of risk management, BCM can also contribute significantly to the optimization of organization performance.

A few of present literature which focus on the strategic role of BCM, posited that $\mathrm{BCM}$ can provide organizations with sources of competitive advantage, but these studies have not deliberated comprehensively on how BCM could influence the organizational performance specifically (Alesi, 2008; Herbane et al., 2004; Herbane, 2010; Selden \& Perks, 2007). Additionally, Sawalha (2013) postulates that the relationship between $\mathrm{BCM}$ and organizational performance was found to be mainly underexplored by the researchers. He claims that his research is the first that examines the influence of $\mathrm{BCM}$ on the various elements of organizational performance, subsequently highlighting the value add and significance of BCM strategically. In his study on the Jordanian banking sector involving 11 out of 17 banks, one of the most important roles of BCM is to provide customers with uninterruptible and secured banking services at all time. This capability lays the foundations for preserving a positive corporate reputation, enhances the competitive advantage against the competitors, increase profitability, and subsequently improves the overall organizational performance. The qualitative study also reveals that BCM has a significant role in improving profitability. Based on the interviews, 100 percent of respondents asserted that $\mathrm{BCM}$ implementation ensure banking operations and critical business functions are preserved uninterrupted before, during and after an unexpected incident, hence making sure that banking transactions are carried out continuously by the customers (Sawalha, 2013). Besides the financial performance, his study also discovered that BCM also have positive effect on several non-financial performance indicators such as effectiveness, efficiency, quality, innovation, productivity and quality of work life.

\section{IT Capability}

The concept of IT capability was introduced by Ross, Mathis and Dale (1996). They asserted that the success of organizations cannot be guaranteed by IT alone, but by organizations' IT capability to employ IT to support dynamic business opportunities. In other words, organizations cannot only rely on acquiring IT infrastructure as a necessary condition to sustain the competitive advantage, but they must also acquire and nurture internal capabilities to effectively manage the infrastructure (Jacks, Palvia, Schilhavy, \& Wang, 2011). IT capability is defined as a firm's ability to acquire, deploy, and leverage its IT related resources in combination with other resources in order to achieve, gain and maintain competitive advantage and business objectives through IT implementation.

During its early days, DRP which is a component of BCM, focused predominantly on the continuous operability and recovery of computing systems to counteract against man-made or natural disasters. Since then, BCM was viewed as an IT issue and the activities was led by an IT function, normally IT managers (Gibb \& Buchanan, 2006; Pitt \& Goyal, 2004; Solms \& Botha, 2004). In this study, the author will investigate the technological capability in another perspective via investigating the role of IT capability as a moderator of the relationship between $\mathrm{BCM}$ and organizational performance. Tippins and Sohi (2003) suggested the conception of IT competency, in this study refers as IT capability, consisting of three main components namely IT knowledge, IT operations and IT objects. IT knowledge concerns the extent to which an organization possesses a body of technical knowledge about objects, such as computer-based systems (Tippins \& Sohi, 2003). In relation to BCM, IT knowledge may comprise of the development of risk assessment profile, business impact analysis, business continuity policies and procedures, awareness program and training. IT operations are conceptualized as the extent to which an organization utilizes IT to manage market and customer information (Tippins \& Sohi, 2003). From the perspective of BCM, IT operations comprise of preventive, repressive and corrective action plans where it covers both the prevention of interruptions and minimizing the impact to business in the event of crisis situation. IT operations will ensure uninterrupted and continuous service availability to enhance customer satisfaction, rather than solely focusing on technology matters. IT objects represents computer-based hardware, software, and supporting personnel (Tippins \& Sohi, 2003). For purpose this research, the conceptualization of IT objects represents IT based hardware, software and network components as well as supporting human resources. In view of BCM, IT objects comprise of the BCM infrastructure such as backup system, redundancy in communication network, data replication strategy, off-site data center and operation center facilities.

\section{Hypothesis}

Based on the above discussions, this study attempts to fill the gaps by providing empirical evidence on the relationships that exist between BCM factors and organizational performance with the moderating effect of IT capability. The relationship between BCM factors, IT capability and organizational performance is based on the Resource Based View (RBV) theory that proposes the performance of an organization is influenced by internal resources. An organization achieves better performance than its competitors by effectively utilizes its internal resources. IT capability is a dynamic capability and it will eventually affect the organizational performance. However, in order to foster distinctive capabilities, the resources must be rare, valuable, non-imitable, non-transferable and non-substitutable (Barney, 1991).

The relationship between BCM factors and organizational performance is also explained by the crisis management theory that highlighted the importance of organization readiness in responding to unexpected crisis events that may hinder or impede normal business operations, thus threatening the achievement of organizational objectives (Pearson \& Clair, 1998). Jafari et al. (2011) postulates that when a company is capable to avoid the adverse impacts of external risks and respond to the environmental changes, it will be less vulnerable to financial consequences of market disparity. In other words, when an organization manages its risks effectively, it will successfully adapt to changes in market conditions and profit variation will be minimized.

The high level hypotheses statements of this study are as follows:

H1a: The IT capability significantly moderates the relationship between the BCM factors and the overall organizational performance. H1b: The IT capability significantly moderates the relationship between the BCM factors and the financial performance.

H1c: The IT capability significantly moderates the relationship between the BCM factors and the non-financial performance.

\section{Research methodology}


This study utilized the survey method which is predominantly quantitative in nature. It is an empirical research which analyses BCM factors as the independent variable whereas organizational performance is analyzed as the dependent variable. This study also examined the moderating effect of IT capability on the relationship between BCM factors and organizational performance. The research setting was a cross-sectional study design where it involves collecting the data only once or at one point in time to meet the research objectives (Cavana, Delahaye, \& Sekaran, 2001). The approach was adopted because of budget and time constraints especially when undertaking research for the purpose of academic programs which is usually limited in time and budget (Cooper \& Schindler, 2003; Saunders, Lewis, \& Thornhill, 2000)

\section{Response Rate}

For this study, the target population is 147 organizations which have obtained the ISO 27001 and/or ISO 22301 certification from SIRIM. The target respondent for the survey will be limited to managers or executive positions that involve directly in the implementation and operational of $\mathrm{BCM}$ within the organizations. These respondents are presumably well-versed in implementing and maintaining BCM programs. They could also participate in strategic decision-making for opportunities and issues in relation to BCM. These group of respondents such as managers and executive is similar to respondents used in previous studies on BCM (Chow \& Ha, 2009; Järveläinen, 2013; Lindström, Samuelsson, \& Hägerfors, 2010). In this study, various methods of data collection were utilized which include self-administered approach and distribution of questionnaires via electronic and conventional mails. Efforts were made to increase the response rate such as by reminding the respondents via telephone call and electronic mail. As a result, 79 responses were gathered from 140 questionnaires distributed which make the response rate of 56.42 percent. Out of these 79 responses collected, 77 questionnaires were useable for further analysis making an effective response rate of 55 percent. According to Babbie (2004) and Zikmund (1991), this quantity of sample obtained is adequate for multivariate analyses and reporting as they advocated for a minimum of 50 percent response rate. On the same note, Sekaran (2003) argued that a response rate of 30 percent is acceptable for surveys.

\section{Instrument Reliability}

A reliability analysis was conducted on the scale to ascertain the applicability of the instrument. Nunally (1978) recommended the minimum 0.70 is the acceptable level of Cronbach's Alpha and if otherwise, the item that will improve Cronbach's alpha when deleted is determined. For this study, the reliability coefficients for all measurement items that exemplify the dimensions generated by factor analysis were ranges from 0.851 to 0.944 that indicate good reliability. Hence, no item was deleted during reliability analysis. Table 1 presents the summary of the reliability analysis results.

Table 1: Reliability Test Results for All the Variables

\begin{tabular}{llll}
\hline Variable & $\begin{array}{l}\text { No of } \\
\text { Items }\end{array}$ & $\begin{array}{l}\text { No of } \\
\text { Items } \\
\text { Deleted }\end{array}$ & $\begin{array}{l}\text { Cronbach's } \\
\text { Alpha }\end{array}$ \\
\hline $\begin{array}{l}\text { Management Support } \\
\begin{array}{l}\text { External Requirement } \\
\text { Organization }\end{array}\end{array}$ & 5 & 0 & 0.888 \\
$\begin{array}{l}\text { Preparedness } \\
\text { Embeddedness of }\end{array}$ & 9 & 0 & 0.888 \\
$\begin{array}{l}\text { Continuity Practices } \\
\begin{array}{l}\text { IT Capability } \\
\text { Financial Performance }\end{array}\end{array}$ & 4 & 0 & 0.921 \\
$\begin{array}{l}\text { Non-Financial } \\
\text { Performance }\end{array}$ & 7 & 0 & 0.851 \\
\hline
\end{tabular}

\section{Hierarchical regression analysis}

A hierarchical regression or moderator regression has been recommended by many scholars as the technique for analyzing the moderating effect (Baron \& Kenny, 1986; Frazier, Tix, \& Barron,
2004). Prior to conducting the hierarchical regression analysis, multiple regression analysis was carried out to determine the effect of predictor variables on criterion variable so as to analyze the power of predictor variables. Russ and McNeilly (1995) suggested that a less stringent significance level of $p<0.25$ should be utilized to address the lack of power in detecting the effect of the moderator. For this study, three levels of significance namely 1 percent, 5 percent and 10 percent were used to detect the moderating effect of IT capability on the relationship between $\mathrm{BCM}$ factors and organizational performance. In order to test the moderator effect, a three step hierarchical regression analysis was performed to ascertain what proportion to the variance in a particular variable is explained by other variables when these variables were entered into the regression analysis in a particular order. The result of the hierarchical regression analysis gave the answer to the research question of the study.

Hierarchical Regression Analysis: Moderating Effect of IT Capability on the Relationship between BCM Factors and Overall Organizational Performance

In order to test the extent of IT capability moderates the relationship between BCM factors and overall organizational performance, a hierarchical multiple regression was conducted. Table 2 exhibits the results of hierarchical regression analysis. BCM factors were entered first in step 1, explaining $80.2 \%$ of the variance. After the entry of IT capability in step 2 the total variance explained by the model as a whole was $80.8 \%$. In step 3 , the interaction terms were entered, which resulted in an additional variance explaining up to $83.9 \%$. The Sig. F Change from step 1 to 2 was not significant (Sig. F change $=0.170$ ) and from step 2 to 3 was significant at the 0.05 significance level (Sig. $\mathrm{F}$ change $=0.029$ ). However, inspection of the individual interaction terms between IT capability x Organization Preparedness $(\beta=-0.187$, $\mathrm{t}=-1.939, \mathrm{p}=.057$ and IT capability $\mathrm{x}$ Embeddedness of Continuity Practices $(\beta=0.263, \mathrm{t}=1.951, \mathrm{p}=.055)$ indicates that Organization Preparedness and Embeddedness of Continuity Practices were significant at $\alpha=0.1$ level. The Durbin-Watson value of 1.754 is within the acceptable range of $2.00 \pm 0.50$ which indicates that the assumption of independence of error terms is not violated. Hence, IT capability moderates the relationship between the BCM factors (Organization Preparedness and Embeddedness of Continuity Practices) and overall organizational performance. Given that IT capability does have direct influence on the overall organizational performance, it emerges as a quasi moderator rather than a pure moderator. Based on the result, it can be concluded that hypotheses H1a-3 and H1a-4 are supported while hypotheses H1a-1 and H1a-2 are rejected.

Table 2: Hierarchical Regression Results: Moderating Effect of IT Capability on the Relationship between BCM Factors and Overall Organizational Performance

\begin{tabular}{|c|c|c|c|}
\hline Variables & $\begin{array}{l}\text { Std } \\
\text { Beta } \\
\text { Step } 1\end{array}$ & $\begin{array}{l}\text { Std } \\
\text { Beta } \\
\text { Step 2 }\end{array}$ & $\begin{array}{l}\text { Std } \\
\text { Beta } \\
\text { Step } 3\end{array}$ \\
\hline \multicolumn{4}{|l|}{ Independent Variable } \\
\hline Management Support & .052 & .014 & .047 \\
\hline External Requirement & .559 & .564 & .513 \\
\hline Organization Preparedness & .014 & .024 & -.009 \\
\hline $\begin{array}{l}\text { Embeddedness Of Continuity } \\
\text { Practices }\end{array}$ & .317 & .277 & .277 \\
\hline \multicolumn{4}{|l|}{ Moderating Variable } \\
\hline \multicolumn{3}{|l|}{ Interaction } & .200 \\
\hline $\begin{array}{l}\text { Management Support x IT } \\
\text { Capability }\end{array}$ & & & -.008 \\
\hline $\begin{array}{l}\text { External Requirement x IT } \\
\text { Capability }\end{array}$ & & & .089 \\
\hline $\begin{array}{l}\text { Organization Preparedness x IT } \\
\text { Capability }\end{array}$ & & & $-.187^{*}$ \\
\hline $\begin{array}{l}\text { Embeddedness Of Continuity } \\
\text { Practices x IT Capability }\end{array}$ & & & $.263^{*}$ \\
\hline $\mathrm{R}$ & .802 & .808 & .839 \\
\hline $\mathrm{R}^{2}$ Change & .643 & .009 & .051 \\
\hline F Change & 32.386 & 1.924 & 2.874 \\
\hline $\begin{array}{l}\text { Sig F Change } \\
\text { Durbin-Watson }\end{array}$ & .000 & 170 & $\begin{array}{l}.029 \\
1.754\end{array}$ \\
\hline
\end{tabular}


capability does have direct influence on the non-financial

Hierarchical Regression Analysis: Moderating Effect of IT Capability on the Relationship between BCM Factors and Financial Performance In order to test the extent of IT capability moderates the relationship between BCM factors and financial performance, a hierarchical multiple regression was conducted. Table 3 exhibits the results of hierarchical regression analysis. BCM factors were entered first in step 1, explaining $73.9 \%$ of the variance. After the entry of IT capability in step 2 the total variance explained by the model as a whole was $74.0 \%$. In step 3 , the interaction terms were entered, which resulted in an additional variance explaining up to $75.9 \%$. The Sig. F Change from step 1 to 2 and from step 2 to 3 were not significant at 0.645 and 0.342 respectively. Furthermore, inspection of the individual interaction terms between BCM factors and IT capability indicate that all interactions were not significant. The Durbin-Watson value of 1.738 is within the acceptable range of $2.00 \pm 0.50$ which indicates that the assumption of independence of error terms is not violated. As such, IT capability does not moderate the relationship between the BCM factors (Management Support, External Requirement, Organization Preparedness, Embeddedness of Continuity Practices) and financial performance. Based on the result, it can be concluded that all of the related hypotheses namely H1b-1, H1b-2, H1b-3 and H1b-4 are rejected.

Table 3: Hierarchical Regression Results: Moderating Effect of IT Capability on the Relationship between BCM Factors and Financial Performance

\begin{tabular}{ll} 
Variables & Std Beta \\
\hline Independent Variable & \\
Management Support & -.025 \\
External Requirement & .625 \\
Organization Preparedness & .047 \\
Embeddedness Of Continuity Practices & .177
\end{tabular}

\section{IT Capability}

Interaction

Management Support x IT Capability

External Requirement $x$ IT Capability

Organization Preparedness $x$ IT Capability

Embeddedness Of Continuity Practices x IT Capability $\mathrm{R}$

$\mathrm{R}^{2}$ Change

F Change

Sig F Change

Durbin-Watson

Significant levels: ${ }^{* *} p<0.001,{ }^{* *} p<0.05,{ }^{*} p<0.1$ performance, it emerges as a quasi moderator rather than a pure moderator. Based on the result, it can be concluded that hypotheses H1c-3 and H1c-4 are supported while hypotheses H1c-1 and H1c-2 are rejected.

Table 4: Hierarchical Regression Results: the Moderating Effect of IT Capability on the Relationship between BCM Factors and NonFinancial Performance

\begin{tabular}{llll} 
Financial Performance & & & \\
\hline Variables & Std & Std & Std \\
& Beta & Beta & Beta \\
& Step 1 & Step 2 & Step 3 \\
\hline
\end{tabular}

Independent Variable

Management Support

External Requirement

Organization Preparedness

Embeddedness Of Continuity

Practices

Moderating Variable

IT Capability

Interaction

Management Support x IT

Capability

External Requirement x IT

Capability

Organization Preparedness x IT

$\begin{array}{lll}.096 & .047 & .084\end{array}$

$-.009 \quad .004 \quad-.027$

$-.027$

$\begin{array}{lll}.374 & .322 & .323\end{array}$

Capability

Embeddedness Of Continuity

Practices x IT Capability

Bteqhangstd Beta Step 2

Sig F Changeg

Durbin-Wątợn

24.487

149

.233

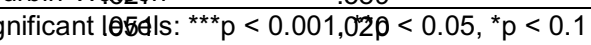

$.162 \quad .162$

Based on the above hierarchical regression analyses, Table 5 summarizes 44 te result of hypdtheses testing of the moderating effect of IT capability on the relationship between BCM factors and organizational performance. .000

Table 5: Summary of hypothes.jsfesting results

\begin{tabular}{|c|c|c|}
\hline Hypoth & .7480 thesis Statemejo & Result \\
\hline esis No & $.001 \quad .029$ & \\
\hline $\mathrm{H} 1 \mathrm{a}$ & $\begin{array}{l}\text { Ifyapability significant } 4 \text { moderates the } \\
\text { relationship between } 34 \text { e BCM factors and }\end{array}$ & $\begin{array}{l}\text { Partially } \\
\text { supported }\end{array}$ \\
\hline
\end{tabular}

$21.658 \mathrm{H1a} \quad$ reapability significant 1 moderates the

.000

Hierarchical Regression Analysis: Moderating Effect of IT Capability on the Relationship between BCM Factors and Non-Financial Performance

In order to test the extent of IT capability moderates the relationship between BCM factors and non-financial performance, a hierarchical multiple regression was conducted. Table 4 exhibits the results of hierarchical regression analysis. BCM factors were entered first in step 1 , explaining $77.2 \%$ of the variance. After the entry of IT capability in step 2 the total variance explained by the model as a whole was $78.2 \%$. In step 3, the interaction terms were entered, which resulted in an additional variance explaining up to $81.8 \%$. The Sig. F Change from step 1 to 2 at the 0.1 significance level (Sig. F change $=0.093$ ) and from step 2 to 3 was significant at 0.05 level (Sig. $\mathrm{F}$ change $=0.026$ ). However, inspection of the individual interaction terms between IT capability $\mathrm{x}$ Organization Preparedness $(\beta=-0.173$, $\mathrm{t}=-1.700, \mathrm{p}=0.094$ and IT capability $\mathrm{x}$ Embeddedness of Continuity Practices $(\beta=0.285, \mathrm{t}=2.005, \mathrm{p}=0.049)$ indicates that Organization Preparedness and Embeddedness of Continuity Practices were significant at $\alpha=0.1$ and $\alpha=0.05$ level respectively. The DurbinWatson value of 1.997 is within the acceptable range of $2.00 \pm 0.50$ which indicates that the assumption of independence of error terms is not violated. Hence, IT capability moderates the relationship between the BCM factor (Organization Preparedness and Embeddedness of Continuity Practices) and non-financial performance. Given that IT

the overall organizational performance. IT capability significantly moderates the relationship between the management support and the overall organizational

Not performance.

H1a-2 IT capability significantly moderates the relationship between the external requirement and the overall organizational performance.

H1a-3 IT capability significantly moderates the relationship between the organization preparedness and the overall organizational performance.

H1a-4 IT capability significantly moderates the relationship between the embeddedness of continuity practices and the overall organizational performance.

$\mathrm{H} 1 \mathrm{~b} \quad$ IT capability significantly moderates the relationship between the BCM factors and the financial performance.

$\mathrm{H} 1 \mathrm{~b}-1 \quad$ IT capability significantly moderates the relationship between the management support and the financial performance.

$\mathrm{H} 1 \mathrm{~b}-2 \quad$ IT capability significantly moderates the relationship between the external requirement and the financial performance.

H1b-3 IT capability significantly moderates the relationship between the organization preparedness and the financial $-.173^{*}$ $.285^{\star \star}$

.818

$016 \quad .058$

$\begin{array}{ll}2.898 & 2.948 \\ .093 & .026\end{array}$

\section{supported}

Not

supported

Supported

Supported performance. 


\section{$\mathrm{H} 1 \mathrm{~b}-4 \quad$ IT capability significantly moderates the} relationship between the embeddedness of continuity practices and the financial performance.

H1c IT capability significantly moderates the relationship between the BCM factors and the non-financial performance.

H1c-1 IT capability significantly moderates the relationship between the management support and the non-financial performance.

H1c-2 IT capability significantly moderates the relationship between the external requirement and the non-financial performance.

H1c-3 IT capability significantly moderates the relationship between the organization preparedness and the non-financial performance.

H1c-4 IT capability significantly moderates the relationship between the embeddedness of continuity practices and the non-financial performance.

\section{Discussion on findings}

The outcome of this study revealed a mixed result on the interaction effect between IT capability and the individual BCM factors. Firstly, this study found that IT capability partially moderates relationship between two BCM factors and overall organizational performance namely organization preparedness and embeddedness of continuity practices. Similarly, the study also found that IT capability partially moderates relationship between two BCM factors and nonfinancial performance namely organization preparedness and embeddedness of continuity practices These results are consistent with the literature on RBV which suggest that organizations possess resources which empower them to gain competitive advantage and leads to sustaining superior long-term performance (Barney, 1991; Grant, 1991). Similarly, many of previous researchers have adopted the perspective of RBV in linking IT to firm performance (Liang, You, \& Liu, 2010; Santhanam \& Hartono, 2003; Yongmei, Hongjian, \& Junhua, 2008).

The results demonstrate that embeddedness of continuity practices has significant direct and indirect effects on the overall organizational performance where the indirect effect is achieved via IT capability. This means that organizations which have embedded good BCM practices within their operations would also require an effective IT capability in order to achieve higher level of overall organizational performance and non-financial performance. Previous studies argued that the embeddedness of continuity practices facilitates the effective implementation of information system continuity management and necessitates stability and a clear organizational structure (Elliott, Swartz, \& Herbane, 2010b). Complementary to this, Järveläinen (2013b) suggested that one way of embedding continuity practices in an organization is to adopt an international standard or framework that comprehensively integrates it into the existing processes. The suggestion is in line with the population of this study which has adopted ISO 27001 and/or ISO 22301 standards as part of their effort to enhance their BCM competency and improve operational stability. From the IT capability perspective, these ISO standards represent the IT knowledge and IT operations elements possessed by the organizations.

However, the result also depicts that the higher the organization preparedness, the lower the non-financial performance. When the level of organization preparedness is lower, those organizations with less emphasis on IT capability appear to achieve higher level of nonfinancial performance. However, when the level of organization preparedness is higher, those organizations with high emphasize on IT capability experience a significant reduction in non-financial performance. In other words, higher non-financial performance is achieved when there is lower level of organization preparedness and lower level of emphasize on IT capability. The contradicting finding may be resulted from lack of regular exercise of BCM plan as observed from the feedback of the respondent of this study. Even though most of the respondents of this study have indicated that they are adequately prepared and had heavily invested in term of their IT infrastructure, this study found that the BCM plans were not regularly tested by some of the organizations under study, which could render them impractical and useless (Gibb \& Buchanan, 2006). This finding is also supported by Pearson and Woodman (2012) who reported that 52 percent of their respondents did not exercised their BCM plan in year 2011 while 17 percent said that they had never tested their BCM plan. In addition, Rosenthal and Sheniuk (1993) argued that, unless BCM plans are periodically and regularly tested, they are seldom usable operationally.

Secondly, for the financial performance, the results of the hierarchical regression analysis revealed that the interaction effects between all four BCM factors and IT capability were found to be insignificant. In other words, it can be expressed that IT capability does not moderate the relationship between BCM factors and financial performance. The result of this study contradicts the findings of Sawalha (2013b) which highlighted that providing reliable services will enhance corporate reputation, competitive advantage and profitability. On the other hand, $\mathrm{Li}$ and $\mathrm{Ye}$ (1999) discovered that IT investment was not statistically significant in enhancing profitability when measured by return on assets and return on sales. A reasonable explanation for this contradicting finding may be due to the fact these $\mathrm{BCM}$ factors are commonly seen relates to operational performance and not directly affecting the financial bottom line. This assumption is supported by KPMG (2014) who reported that some organization did not realize the total cost of the downtime. Thus, it can be inferred from the results of the study that it is important for organization to recognize the cost of downtime to the business to appreciate the contribution of BCM on the financial performance. This proposition can be achieved by conducting a business impact analysis. Although the success of BCM implementation is influenced by the use of appropriate technology and availability of robust IT infrastructure, this study found that greater extent of IT capability is not beneficial to strengthen the relationship between $\mathrm{BCM}$ factors and financial performance. According to Lingeswara and Tammineedi (2012), this phenomenon may occur if during the planning stage of developing organizational resilience plan, too much focus is given on technology and does not provide equal importance to other organizational resources such as employees, premises, data, processes and supplies. To overcome this issue, the scope of a BCM program should be expanded to cater for wider causes of disasters that may affect the business (Elliott et al., 2010b).

In summary, the results of the study demonstrate the moderating effect of IT capability on the relationship between BCM factors and organizational performance. These findings support the current literature which has established the continual importance of IT capability in the creation of business values and sustaining competitive advantage in the digital era.

\section{Limitations and recommendations for future research}

Although the study found several encouraging results, it is important to recognize that the current findings also have several limitations. The identified limitations of the study formed the basis for the recommendations for future research endeavors.

Firstly, this study only focusing on the organizations which have obtained the ISO 27001 and ISO 22301 certifications with the rationale that these organizations are deemed to possess considerably higher sense of commitment towards BCM by enhancing their capability in line with the internationally recognized standards. At present, the number of these organizations in Malaysia is relatively small which is less than 150. According to Anderson and Gerbing (1988), a sample size of 150 or more usually provides parameter estimates that have standard errors, which are small enough to be of practical usefulness. Thus, future studies may want to consider 
extending the scope of the study to cover other organizations even without the $\mathrm{BCM}$ related certifications so as to determine the effect of the adoption of the BCM standards on the effectiveness of BCM implementation which eventually contribute to the organizational performance. A comparative analysis can also be made between organizations with $\mathrm{BCM}$ related certifications against those without such certification. By expanding the scope of the study which will directly increase the size of population, it may perhaps improve the quality of data and inherently enhance the generalizability of findings. The larger the sample size, the smaller the error and the higher the precision of the results (Cohen, 1988). Hence, this will strengthen the probability of detecting the phenomena under study.

The second recommendation relates to the methodological approach. As the survey research adopted by this study was based on crosssectional approach, further efforts needs to be carried out to establish the effects of changes over a longer period of time in the aspect of BCM. Using a longitudinal approach on the similar group of participants may be better at drawing the BCM effects on the organizational performance and perhaps could provide a better analysis on the interrelationships among the organizations under study. Whereas a cross sectional study only focuses on a small sample at a particular time and the conclusion would be drawn with regards to certain phenomena of a larger population. In other words, the main advantage of longitudinal approach is that it enabled the researcher to observe changes that take place over time. Hair et al. (2007) argued that longitudinal study is a better way to seek the cause and effect relationship among variables at a different period of time. As such, this approach apparently can help the researcher to understand in more detail on the relationship between BCM, IT capability and organizational performance in Malaysian organizations. Thus, future research should consider a longitudinal study to investigate the implementation of BCM and how it influences the organizational performance.

\section{Conclusion}

Organizations from both the private and public sectors have to be more prepared to counter any undesirable crisis and ensure that the interruptions to their business operations are kept at a very minimal possible. Any critical operational failure may cause a degradation of service quality and even a monetary loss if the duration or degree of business interruption is extensive (Yiu \& Tse, 1995).

The overall findings from this study have proven the association between IT capabilities on the relationship between BCM factors and organizational performance. The linkage between these variables provides a new empirical contribution to academic knowledge and practitioners. In general, this study contributed some insights to the managers and practitioners especially in the Malaysian organization setting. Organizations are encouraged to invest in terms of financial, time, resources and commitment to enhance their IT capability in order to further benefit from the implementation of BCM which eventually may lead to improved organizational performance. With regards to IT capability, managers need to look beyond specific technology where all three dimensions namely IT knowledge, IT operations and IT objects are essential to be present in order to achieve optimum result.

The researchers hope that the outcome of this research will assist the managers, business and IT professionals to justify further investment and effort in improving the BCM knowledge, processes and infrastructure. In addition, this study could provide better understanding to the decision makers on the significant role of $\mathrm{BCM}$ in relation to the organizational performance and encourage their participation at the strategic level.

\section{References}

Alesi, P. (2008). Building enterprise-wide resilience by integrating business continuity capability into day-to-day business culture and technology. Journal of Business Continuity \& Emergency Planning, 2, 214-220.
Anderson, J. C., \& Gerbing, D. W. (1988). Structural Equation Modeling in practice: A review and recommended two-step approach. Psychological Bulletin, 103, 411-423.

Babbie, E. (2004). The practice of social research (10th ed.). Belmont California: Thomson/Wadsworth Learning.

Barney, J. B. (1991). Firm Resources and Sustained Competitive Advantage. Journal of Management, 17(1), 99-120.

Baron, R. M., \& Kenny, D. a. (1986). The moderator-mediator variable distinction in social psychological research: conceptual, strategic, and statistical considerations. Journal of Personality and Social Psychology, 51(6), 1173-82. Retrieved from http://www.ncbi.nlm.nih.gov/pubmed/3806354

Belaouras, S. (2009). State of Business Continuity Preparedness. Disaster Recovery Journal, 22(1). Retrieved from $\mathrm{http}: / /$ www.drj.com/index.php?option=com_content\&task=view\&id=2206 \&Itemid $=676$

Cavana, R., Delahaye, B. L., \& Sekaran, U. (2001). Applied business research: qualitative and quantitative methods. Singapore: Markono Print Media Ltd.

Childs, D., \& Dietrich, S. (2002). Contingency Planning and Disaster Recovery: A Small Business Guide. Hoboken, NJ.: John Wiley \& Sons.

Chow, W. S. (2000). Success factors for IS disaster recovery planning in Hong Kong. Information Management \& Computer Security, 8(2), 80-87. doi:10.1108/09685220010321326

Chow, W. S., \& Ha, W. O. (2009). Determinants of the critical success factor of disaster recovery planning for information systems. Information Management \& Computer Security, 17(3), 248-275. doi:10.1108/09685220910978103

Cohen, J. (1988). Statistical power analysis for the behavioral sciences (2nd ed.). Hillsdale, NJ: Erlbaum.

Cooper, D., \& Schindler, P. (2003). Business Research Methods (8th ed.). McGraw Hill.

Elliott, D., Swartz, E., \& Herbane, B. (2010a). Business Continuity Management - A crisis management approach (2nd ed.). London: Routledge.

Elliott, D., Swartz, E., \& Herbane, B. (2010b). Business continuity management: a crisis management approach (2nd ed.). New York, USA: Routledge.

Frazier, P. A., Tix, A. P., \& Barron, K. E. (2004). Testing moderator and mediator effects in counselling psychology research. Journal of Counselling Psychology, 51(1), 115-134.

Gibb, F., \& Buchanan, S. (2006). A framework for business continuity management. International Journal of Information Management, 26(2), $128-141$ http://www.sciencedirect.com/science/article/B6VB4-4JN2P511/2/57980f789e3c81f88a500981a33a3b45

Grant, R. M. (1991). The Resource-Based Theory of Competitive Advantage: ImpHcations for Strategy Formulation. California Management Review, 33, 37-40.

Hair, J., Money, A. H., Page, M., \& Samouel, P. (2007). Editors, Research Methods for Business. West Sussex, England: John Wiley \& Sons.

Hecht, J. (2002). Business Continuity Management. Communications of the Association for Information Systems, 10, 444-450.

Herbane, B. (2010). The evolution of business continuity management: A historical review of practices and drivers. Business History, 52(6), 9781002. doi:10.1080/00076791.2010.511185

Herbane, B., Elliott, D., \& Swartz, E. M. (2004). Business Continuity Management: time for a strategic role? Long Range Planning, 37(5), 435457. doi:10.1016/j.1rp.2004.07.011

Hoong, L. L. (2011). Factors Influencing the Success of the Disaster Recovery Planning Process: A Conceptual Paper. In Research and Innovation in Information Systems (ICRIIS), 2011 International Conference.

Jacks, T., Palvia, P., Schilhavy, R., \& Wang, L. (2011). A framework for the impact of IT on organizational performance. Business Process Management Journal, 17(5), 846-870. doi:10.1108/14637151111166213

Jafari, M., Chadegani, A., \& Biglari, V. (2011). Effective risk management and company's performance: investment in innovations and intellectual capital using behavioural and practical approach. International Research Journal of Finance and Economics, 3(15), 780-786. doi:10.5897/JEIF11.123

Järveläinen, J. (2013). IT incidents and business impacts: Validating a framework for continuity management in information systems. International Journal of Information Management, 33(3), 583-590. doi:10.1016/j.ijinfomgt.2013.03.001

Karim, A. J. (2011). Business Disaster Preparedness: An Empirical Study for measuring the Factors of Business Continuity to face Business Disaster. International Journal of Business \& Social Science, 2(18), 183-192. Retrieved 
http://search.ebscohost.com/login.aspx?direct=true \&db=bth\&AN=667265 $42 \&$ site $=$ ehost-live

KPMG. (2014). The 2013-2014 Continuity Insights and KPMG LLP Global Business Continuity Management (BCM) Program Benchmarking Study.

Li, E. Y., Chen, J. S., \& Huang, Y. H. (2006). A framework for investigating the impact of IT capability and organisational capability on firm performance in the late industrialising context. International Journal of Technology Management, 36(1/2/3), 209. doi:10.1504/IJTM.2006.009969

Li, M. L., \& Ye, L. R. (1999). Information technology and firm performance: linking with environmental, strategic and managerial. Information \& Management, 35(1), 43-51.

Liang, T. P., You, J. J., \& Liu, C. C. (2010). A resource-based perspective on information technology and firm performance: a meta analysis. Industrial Management \& Data Systems, 110(8), 1138-1158. doi:10.1108/02635571011077807

Lindström, J., Samuelsson, S., \& Hägerfors, A. (2010). Business continuity planning methodology. Disaster Prevention and Management. doi:10.1108/09653561011038039

Lingeswara, R., \& Tammineedi, S. (2012). Key Issues, Challenges and Resolutions in Implementing Business Continuity Projects. ISACA Journal, 1, 20-23.

Nunally, J. C. (1978). Psychometric Theory (2nd ed.). New York: McGrawHill.

Pearson, C. M., \& Clair, J. A. (1998). Reframing Crisis Management. The Academy of Management Review, 23(1), 59-76. doi:10.2307/259099

Pearson, G., \& Woodman, P. (2012). The 2012 Business Continuity Management Survey. Chartered Management Institute.

Peterson, C. A. (2009). Business continuity management \& guidelines. 2009 Information Security Curriculum Development Conference on InfoSecCD '09, 114. doi:10.1145/1940976.1940999

Petroni, A. (1999). Managing information systems' contingencies in banks: a case study. Disaster Prevention and Management, 8(2), 101-110. doi:10.1108/09653569910266139

Pitt, M., \& Goyal, S. (2004). Business continuity planning as a facilities management tool. Facilities, 22(3/4), 87-99. doi:10.1108/02632770410527824

Randeree, K., Mahal, A., \& Narwani, A. (2012). A business continuity management maturity model for the UAE banking sector. Business Process Management Journal, 18(3), 472-492. doi:10.1108/14637151211232650

Rockart, J. F. (1979). Chief executives define their own data needs. Harvard Business Review, 57(2), 81-93. Retrieved from http://www.ncbi.nlm.nih.gov/pubmed/10297607

Rosenthal, P. H., \& Sheniuk, G. (1993). Business Resumption Planning: Exercising the Disaster Management team. Journal of Systems Management, 44(6), 12-16.
Ross, J. W., Mathis, C., \& Dale, B. (1996). Develop Long-Term Competitiveness through IT Assets. Sloan Management Review, 38(1), $31-42$.

Russ, F. A., \& McNeilly, K. M. (1995). Links among satisfaction, commitment, and turnover intentions: The moderating effect of experience, gender, and performance. Journal of Business Research, 34, 57-65.

Saleem, S. (2011). Do effective risk management affect organizational performance. European Journal of Business and Management, 3(3), 258268.

Santhanam, R. \& Hartono, E. (2003). Issues in Linking Information Technology Capability to Firm Performance. MIS Quarterly, 27(1), 125 153.

Saunders, M., Lewis, P., \& Thornhill, A. (2000). Research Methods for Business Students (2nd ed.). Harlow, England: Prentice Hall.

Sawalha, I. H. S. (2013). Organisational performance and business continuity management: a theoretical perspective and a case study. Journal of Business Continuity \& Emergency Planning, 6(4), 360-73. Retrieved from http://www.ncbi.nlm.nih.gov/pubmed/23835428

Sekaran, U. (2003). Research methods for business: A skill building approach (4th ed.). New York, NY: John Willey \& Sons.

Selden, S., \& Perks, S. (2007). How a structured BIA aligned business continuity management with Gallaher's strategic objectives. Journal of Business Continuity \& Emergency Planning, 1(4), 348-355.

Solms, R. Von, \& Botha, J. (2004). A cyclic approach to business continuity planning. Information Management \& Computer Security. doi:10.1108/09685220410553541

Tippins, M. J., \& Sohi, R. S. (2003). IT Competency and Firm Performance: Is Organizational Learning a Missing Link? Strategic Management Journal, 761(March), 745-761.

Vancoppenolle, G. (2007). The Definitive Handbook of Business Continuity Management Second Edition. (A. Hiles, Ed.). England: John Wiley \& Sons Ltd.

Wong, W. N. Z. (2009). The strategic skills of business continuity managers: putting business continuity management into corporate long-term planning. Journal of Business Continuity \& Emergency Planning, 4, 6268.

Yiu, K., \& Tse, Y. Y. (1995). A Model for Disaster Recovery Planning. IS Audit \& Control Journal, 5, 45-51.

Yongmei, L. I. U., Hongjian, L. U., \& Junhua, H. U. (2008). IT Capability as Moderator Between IT Investment and Firm Performance. Tsinghua Science and Technology, 13(3), 329-336.

Zikmund, W. G. (1991). Business Research Methods (3rd ed.). Orlando, FL: Dryden. 